\title{
Late sequelae of pulmonary tuberculosis
}

\author{
Karim El-Kersh, ${ }^{1}$ Wasiq Faraz Rawasia ${ }^{2}$
}

${ }^{1}$ Department of Pulmonary, Critical Care \& Sleep Medicine, University of Louisville, Louisville, Kentucky, USA ${ }^{2}$ Department of Medicine, University of Louisville, Louisville, Kentucky, USA

\section{Correspondence to}

Dr Karim El-Kersh

karimelkersh@yahoo.com
To cite: El-Kersh $\mathrm{K}$, Rawasia WF. BMJ Case Rep Published online: [please include Day Month Year] doi:10.1136/bcr-2013 009294

\section{DESCRIPTION}

An 82-year-old Persian woman, with a history of pulmonary tuberculosis as a child, presented with gradual increasing dyspnoea. Her arterial blood gas showed severe respiratory acidosis and she was intubated. Her chest x-ray revealed a significant calcification encasing the majority of the left lung with a predilection towards the lung apex and pleural thickening which was redemonstrated on a subsequent chest CT (figures 1 and 2). She had normal renal function. Serum calcium and phosphorus were normal and she had no history of asbestos exposure. The patient had a hospital course complicated by gastrointestinal bleeding and pneumonia. The family elected comfort care and the patient died after prolonged hospitalisation.

Our patient had extensive pleural calcification secondary to old pulmonary tuberculosis. Late sequelae of tuberculous pleuritis include chronic persistent pleural effusion, empyema necessitatis, bronchopleural fistula, pleural malignancy, fibrothorax and pleural thickening which may be associated with extensive calcification. ${ }^{1}$

Other conditions such as haemothorax, empyema, talcosis, asbestosis and secondary hyperparathyroidism can result in pleural calcification as well. ${ }^{2}$

The distribution of pleural calcification can carry a diagnostic significance, for example, diaphragmatic pleural calcification is highly suggestive of asbestosis and unlikely to be caused by tuberculosis in which the pleural reaction is most commonly apical and asymmetric. ${ }^{2} 3$

Patients with diffuse pleural thickening should be closely monitored for the development of restrictive lung disease with serial pulmonary function tests. The main treatment focus is to treat the

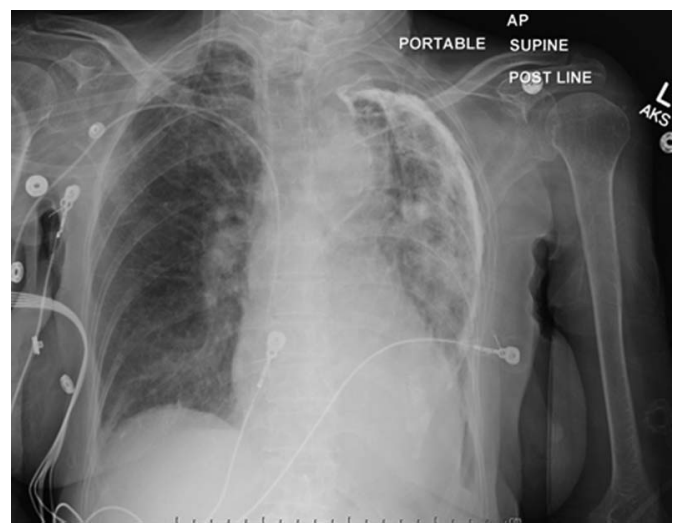

Figure 1 A chest $x$-ray showing significant calcification encasing majority of the left lung with a predilection towards the lung apex with associated underlying pleural thickening.

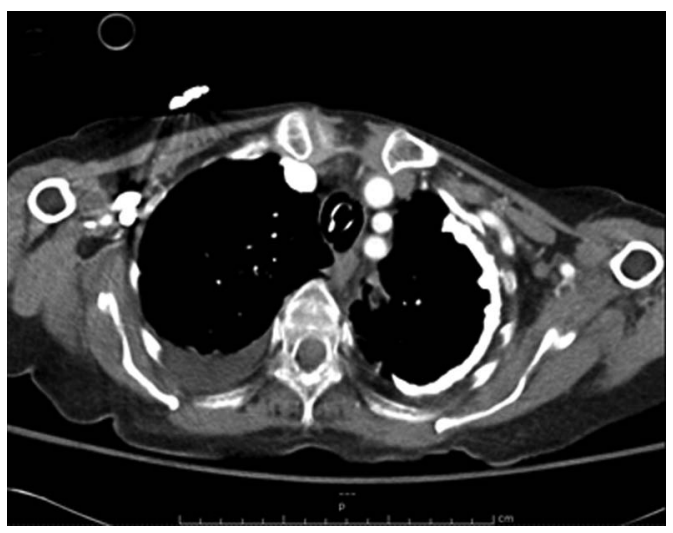

Figure 2 A chest CT showing extensive left pleural calcifications and pleural thickening. The right-sided effusion was found to be transudative on thoracentesis.

underlying disease. Pleural decortication in setting of extensive pleural calcification is of limited value specially with underlying parenchymal lung disease.

\section{Learning points}

- Sequelae of a common disease can manifest itself much later in the course of life and can be missed if a thorough history is not obtained and corroborated with the physical examination findings and imaging.

- Patient's history with regard to travel and/or residence is also essential since the pathological process in question may have been acquired in a totally different geographical location and its sequelae may or may not be very common in the area where it is diagnosed.

Competing interests None.

Patient consent Obtained.

Provenance and peer review Not commissioned; externally peer reviewed.

\section{REFERENCES}

1 Choi JA, Hong KT, Oh YW, et al. CT manifestations of late sequelae in patients with tuberculous pleuritis. AJR Am J Roentgenol 2001;176:441-5.

2 Reed JC. Chest radiology-plain film patterns and differential diagnoses. 4th edn. St. Louis: Mosby 1997:64-5.

3 Palmer PES, Wambani SJ, Reeve P. The imaging of tuberculosis: with epidemiological, pathological, and clinical correlation. Berlin Heidelberg: Springer 2002:24. 


\section{Images in...}

Copyright 2013 BMJ Publishing Group. All rights reserved. For permission to reuse any of this content visit http://group.bmj.com/group/rights-licensing/permissions.

BMJ Case Report Fellows may re-use this article for personal use and teaching without any further permission.

Become a Fellow of BMJ Case Reports today and you can:

- Submit as many cases as you like

- Enjoy fast sympathetic peer review and rapid publication of accepted articles

- Access all the published articles

- Re-use any of the published material for personal use and teaching without further permission

For information on Institutional Fellowships contact consortiasales@bmjgroup.com

Visit casereports.bmj.com for more articles like this and to become a Fellow 